\title{
Barium and Calcium Stimulate Secretion from Digitonin- Permeabilized Bovine Adrenal Chromaffin Cells by Similar Pathways
}

\author{
Daniel R. TerBush and Ronald W. Holz \\ Department of Pharmacology, University of Michigan, Ann Arbor, Michigan, U.S.A.
}

\begin{abstract}
We compared the characteristics of secretion stimulated by EGTA-buffered $\mathrm{Ba}^{2+}$ - and $\mathrm{Ca}^{2+}$-containing solutions in digitonin-permeabilized bovine adrenal chromaffin cells. Half-maximal secretion occurred at approximately 100 $\mu M \mathrm{Ba}^{2+}$ or $1 \mu M \mathrm{Ca}^{2+} . \mathrm{Ba}^{2+}$-stimulated release was not due to release of sequestered intracellular $\mathrm{Ca}^{2+}$ because at a constant free $\mathrm{Ba}^{2+}$ concentration, increasing unbound EGTA did not diminish the extent of release due to $\mathrm{Ba}^{2+}$. The maximal extents of $\mathrm{Ba}^{2+}$ - and $\mathrm{Ca}^{2+}$-dependent secretion in the absence of $\mathrm{MgATP}$ were identical. MgATP enhanced $\mathrm{Ba}^{2+}$ induced secretion to a lesser extent than $\mathrm{Ca}^{2+}$-induced secretion. Half-maximal concentrations of $\mathrm{Ba}^{2+}$ and $\mathrm{Ca}^{2+}$, when added together to cells, yielded approximately additive amounts of secretion. Maximal concentrations of $\mathrm{Ba}^{2+}$ and $\mathrm{Ca}^{2+}$ when added together to cells for 2 or $15 \mathrm{~min}$ were not
\end{abstract}

additive. Tetanus toxin inhibited $\mathrm{Ba}^{2+}$ - and $\mathrm{Ca}^{2+}$-dependent secretion to a similar extent. $\mathrm{Ba}^{2+}$, unlike $\mathrm{Ca}^{2+}$, did not activate polyphosphoinositide-specific phospholipase $\mathrm{C}$. These data indicate that (1) $\mathrm{Ba}^{2+}$ directly stimulates exocytosis, (2) $\mathrm{Ba}^{2+}$-induced secretion is stimulated to a lesser extent than $\mathrm{Ca}^{2+}$-dependent secretion by $\mathrm{MgATP},(3) \mathrm{Ba}^{2+}$ and $\mathrm{Ca}^{2+}$ use similar pathways to trigger exocytosis, and (4) exocytosis from permeabilized cells does not require activation of polyphosphoinositide-specific phospholipase C. Key Words: ATPBarium-Calcium-Chromaffin cell-Exocytosis-Tetanus toxin. TerBush D. R. and Holz R. W. Barium and calcium stimulate secretion from digitonin-permeabilized bovine adrenal chromaffin cells by similar pathways. $J$. Neurochem. 58, 680-687 (1992).
Nicotinic agonist- or elevated $\mathrm{K}^{+}$-induced secretion from bovine adrenal chromaffin cells is critically dependent on influx of extracellular $\mathrm{Ca}^{2+}$ and a subsequent rise in intracellular $\mathrm{Ca}^{2+}$ (Wilson and Kirshner, 1977; Holz et al., 1982; Kilpatrick et al., 1982; Knight and Kesteven, 1983; Kao and Schneider, 1986). Although many processes are activated by $\mathrm{Ca}^{2+}$ within cells [e.g., protein phosphorylation (Amy and Kirshner, 1981; Cote et al., 1986; Lee and Holz, 1986; Pocotte et al., 1986), phospholipase C (Eberhard and Holz, 1987; Sasakawa et al., 1989), and arachidonate release (Frye and Holz, 1984, 1985; Morgan and Burgoyne, 1990)], the process that is responsible for triggering exocytosis is unknown. Extracellular $\mathrm{Ba}^{2+}$, substituted for $\mathrm{Ca}^{2+}$, can enter chromaffin cells through voltagedependent $\mathrm{Ca}^{2+}$ channels (Artalejo et al., 1987; Heldman et al., 1989) and stimulate release of catecholamines (Douglas and Rubin, $1964 a, b$ ). $\mathrm{Ba}^{2+}$ also stim- ulates secretion from other cells (Hales and Milner, 1968; Davidson et al., 1987; van der Merwe et al., 1990). In experiments with intact cells, it is unclear whether intracellular $\mathrm{Ba}^{2+}$ directly triggers secretion or whether $\mathrm{Ba}^{2+}$ acts indirectly by releasing $\mathrm{Ca}^{2+}$ from intracellular stores. This distinction is important because it helps characterize the divalent cation dependency of the secretory pathway. Furthermore, if $\mathrm{Ca}^{2+}$ and $\mathrm{Ba}^{2+}$ stimulate secretion by identical mechanisms, then only those biochemical processes that are activated by both would be necessary for secretion.

In this study we have expanded on recent observations that $\mathrm{Ba}^{2+}$ stimulates secretion from permeabilized chromaffin cells (lzumi et al., 1986; Knight et al., 1988; Heldman et al., 1989). We examined the characteristics of $\mathrm{Ba}^{2+}$ - and $\mathrm{Ca}^{2+}$-dependent secretion and phosphoinositide-specific phospholipase $\mathrm{C}$ activity in digitoninpermeabilized cells using EGTA buffers to control the
Received March 27, 1991; revised manuscript received July 3 . 1991; accepted July 3, 1991.

Address correspondence to Dr. R. W. Holz at Department of Pharmacology, University of Michigan, Ann Arbor, MI 48109-0626, U.S.A.
Abbreviations used: BSA, bovine serum albumin; CBP, calmodulin binding peptide; GTP $\gamma S$, guanosine-5'-O-thiotriphosphate; KGEP, solution containing $140 \mathrm{~m} M$ potassium glutamate, $10 \mathrm{~m} M$ EGTA, $20 \mathrm{mM}$ PIPES (pH 6.6), and $5 \mathrm{mg} / \mathrm{ml} \mathrm{BSA}$; PSS, physiological salt solution. 
amounts of free $\mathrm{Ba}^{2+}$ and free $\mathrm{Ca}^{2+}$ available to stimulate exocytosis. The interactions between $\mathrm{Ba}^{2+}$ and $\mathrm{Ca}^{2+}$, the effects of tetanus toxin, and the effects of MgATP indicate that $\mathrm{Ba}^{2+}$ directly stimulates secretion by a pathway similar to that stimulated by $\mathrm{Ca}^{2+}$. Because $\mathrm{Ba}^{2+}$ is a poor activator of polyphosphoinositidespecific phospholipase $C$ and calmodulin-dependent processes, these experiments limit the biochemical reactions necessary for exocytosis.

\section{EXPERIMENTAL PROCEDURES}

\section{Materials}

All chemicals, except as noted, were purchased from Sigma (St. Louis, MO, U.S.A.). Calf skin collagen and tetanus toxin were acquired from Calbiochem (San Diego, CA, U.S.A.). Amphotericin B (Fungizone) was obtained from Squibb (Princeton, NJ, U.S.A.). $\left[{ }^{3} \mathrm{H}\right]$ Norepinephrine was acquired from Amersham (Arlington Heights, IL, U.S.A.) and myo$\left[2-{ }^{3} \mathrm{H}\right]$ inositol was from American Radiolabeled Chemicals (St. Louis, MO, U.S.A.). Culture plates were purchased from Costar (Cambridge, MA, U.S.A.) and scintillation fluid was from ICN Biomedicals (Irvine, CA, U.S.A.). Digitonin was from Fluka (Ronkonkoma, NY, U.S.A.). Culture medium was from Whitaker Bioproducts (Walkersville, MD, U.S.A.) and Dowex AG1-X8 resin was from Bio-Rad Laboratories (Richmond, CA, U.S.A.).

\section{General tissue culture and experimental conditions}

Primary dissociated cells from bovine adrenal medulla were prepared and maintained as monolayer cultures as previously described by Holz et al. (1982). Chromaffin cells used for determining release of radiolabeled inositol phosphates (Fig. 6) were purified by differential plating (Waymire et al., 1983). Cells were cultured as monolayers in $6.4-\mathrm{mm}$ diameter culture wells at 500,000 cells $/ \mathrm{cm}^{2}$. Culture wells were coated with 5 $\mu \mathrm{g}$ of calf skin collagen $/ \mathrm{cm}^{2}$ prior to cell plating. Three to four days after plating, culture medium was replaced with fresh medium not containing Fungizone. Immediately before an experiment, cells were washed three times for $15 \mathrm{~min}$ with physiological salt solution (PSS) $[145 \mathrm{mM} \mathrm{NaCl}, 5.6 \mathrm{~m} M$ $\mathrm{KCl}, 2.2 \mathrm{mM} \mathrm{CaCl}$, $0.5 \mathrm{~m} M \mathrm{MgCl}_{2}, 5.6 \mathrm{mM}$ glucose, 15 $\mathrm{m} M$ HEPES (pH 7.4), $0.57 \mathrm{mM}$ sodium ascorbate, $5 \mathrm{mg} / \mathrm{ml}$ bovine serum albumin (BSA)]. All experiments were performed at $25^{\circ} \mathrm{C}$ on cells cultured $4-8$ days.

\section{Assay of secretion}

Before an experiment, cells were incubated for $4-24 \mathrm{~h}$ in culture medium containing $\left[{ }^{3} \mathrm{H}\right]$ norepinephrine $(2 \mu \mathrm{Ci} / \mathrm{ml})$ supplemented with $0.1 \mathrm{mg} / \mathrm{ml}$ of ascorbate. After washing with PSS, an experiment was initiated by rendering cells leaky with a KGEP solution [140 $\mathrm{mM}$ potassium glutamate, 10 $\mathrm{m} M$ EGTA, $20 \mathrm{~m} M$ piperazine- $N, N^{\prime}$-bis(2-ethanesulfonic acid (PIPES) (pH 6.6), $5 \mathrm{mg} / \mathrm{ml} \mathrm{BSA]} \mathrm{containing} 20 \mu M$ digitonin, $2 \mathrm{~m} M$ ATP, and $1 \mathrm{~m} M$ free $\mathrm{Mg}^{2+}$ for 4-6 min. In experiments where the effects of ATP on secretion were examined (Figs. 2, 3, and 4A), the cells were rendered leaky in the absence of ATP and $\mathrm{Mg}^{2+}$. The permeabilization solution was removed and replaced with a KGEP solution either containing or lacking $2 \mathrm{mM}$ ATP $\left(1 \mathrm{~m} M\right.$ free $\left.\mathrm{Mg}^{2+}\right)$ and various amounts of $\mathrm{CaCl}_{2}$ and/or $\mathrm{BaCl}_{2}$ buffered to yield free concentrations of 0-10 $\mu M$ for $\mathrm{Ca}^{2+}$ and 0-3 $\mathrm{mM}$ for $\mathrm{Ba}^{2+}$ (see below). After 2-30 min the supernatants were removed and the cells disrupted with $1 \%$ Triton X-100. The amount of radioactivity in the supernatant and the lysed cells was determined by liquid scintillation spectrometry with Universol ES as scintillant. Secretion was the amount of $\left[{ }^{3} \mathrm{H}\right]$ norepinephrine released $(R)$ divided by the sum of that released plus that remaining in the cells $(C)$ for a given data point (i.e., percent secretion $=[R /(R+C)] \times 100)$.

The free concentrations of $\mathrm{Mg}^{2+}, \mathrm{Ca}^{2+}$, and $\mathrm{Ba}^{2+}$ were calculated according to the computer program developed by Chang et al. (1988) using the affinity (stability) constants and protonation constants from Bjerrum et al. (1957). The affinity constants used were:

$\begin{array}{lcr}\text { Metal } & \log K_{\text {MHL }}^{\mathrm{M}} & \log K_{1} \\ \mathrm{Ca}^{2+} & 5.33 & 11.00 \\ \mathrm{Ba}^{2+} & 4.26 & 8.41 \\ \mathrm{Mg}^{2+} & 3.37 & 5.21\end{array}$

The protonation constants used were: $\mathrm{H}_{4} \mathrm{~L}, 2 ; \mathrm{H}_{3} \mathrm{~L}^{-}, 2.68$; $\mathrm{H}_{2} \mathrm{~L}^{2-}, 8.85 ; \mathrm{HL}^{3-}, 9.46$ (expressed as $\log$ base 10 ). A sample KGEP solution (10 $\mathrm{m} M$ EGTA, $2 \mathrm{mM}$ ATP) containing 1 $\mathrm{m} M$ free $\mathrm{Mg}^{2+}, 10 \mu M$ free $\mathrm{Ca}^{2+}$, and $1 \mathrm{~m} M$ free $\mathrm{Ba}^{2+}$ contained total concentrations of $2.55 \mathrm{mM} \mathrm{MgCl}, 7.16 \mathrm{mM}$ $\mathrm{CaCl}_{2}$, and $3.17 \mathrm{~m} M \mathrm{BaCl}_{2}$.

In most secretion experiments (Figs. 2-5; Table 2) D600 $(100 \mu M)$, a $\mathrm{Ca}^{2+}$ channel blocker, was included to ensure that secretion stimulated by $\mathrm{Ba}^{2+}$ came from permeabilized chromaffin cells and not from a small population of unpermeabilized cells. D600, $100 \mu M$, reduced $\mathrm{Ba}^{2+}$-induced secretion from intact cells by $80-90 \%$ which indicates that D 600 is an effective blocker of $\mathrm{Ba}^{2+}$ influx in nonpermeabilized cells. $\mathrm{D} 600,100 \mu M$, reduced $\mathrm{Ba}^{2+}$-induced secretion from digitonin-permeabilized cells by only $18 \% \pm 2 \%(\mathrm{n}=5$ experiments) and had no effect on $\mathrm{Ca}^{2+}$-dependent secretion from permeabilized cells. Several experiments without D600 (Fig. 1 and Table 1) are included in the article to demonstrate that D600 does not qualitatively change the results. Previous studies may have overestimated the amount of $\mathrm{Ba}^{2+}$-dependent secretion from permeabilized cells by not blocking $\mathrm{Ba}^{2+}$. stimulated release from remaining intact cells (Izumi et al., 1986; Knight et al., 1988).

\section{Assay of ${ }^{3} \mathrm{H}$-inositol phosphates}

Cellular inositol-containing lipids were labeled by incubation for $48 \mathrm{~h}$ with $m y o-\left[2-{ }^{3} \mathrm{H}\right]$ inositol $(20 \mu \mathrm{Ci} / \mathrm{ml})$ in Eagle's minimum essential medium (which contained $11 \mu \mathrm{M}$ unlabeled myo-inositol) supplemented with $10 \%$ (vol/vol) dialyzed fetal bovine serum, L-glutamine ( $2 \mathrm{mM})$, penicillin (100 U/ $\mathrm{ml})$, and streptomycin $(100 \mu \mathrm{g} / \mathrm{ml})$. Before an experiment, labeling medium was removed and the cells were washed twice for $10 \mathrm{~min}$ with PSS. Cells were then handled similarly to a secretion experiment except the incubation solution was assayed for released radiolabeled inositol phosphates. Tritiated inositol phosphates were determined by diluting the incubation solutions with $3 \mathrm{ml}$ of $\mathrm{H}_{2} \mathrm{O}$ and applying them to freshly poured columns $(0.3 \mathrm{ml})$ of Dowex AG1-X8 resin (formate form) similar to the method of Eberhard et al. (1990). Free inositol was eluted with $8 \times 1 \mathrm{ml}$ washes with $60 \mathrm{mM}$ sodium formate $/ 5 \mathrm{~m} M$ borax. These washes were usually discarded. Inositol monophosphate was eluted with $3 \times 1 \mathrm{ml}$ washes with $0.2 \mathrm{M}$ ammonium formate $/ 0.1 \mathrm{M}$ formic acid. The 3-ml fraction was collected in a $20-\mathrm{ml}$ scintillation vial and was counted with $15 \mathrm{ml}$ of Universol ES. The columns were then washed $4 \times 1 \mathrm{ml}$ with $0.2 \mathrm{M}$ ammonium formate/ $0.1 M$ formic acid and the solution discarded. Inositol bisphosphate was eluted with $4 \times 1 \mathrm{ml}$ and $4 \times 0.75 \mathrm{ml}$ washes 
with $0.4 \mathrm{M}$ ammonium formate/0.1 $\mathrm{M}$ formic acid and collected into two separate $20-\mathrm{ml}$ scintillation vials as $3.5-\mathrm{ml}$ fractions to which was added $17 \mathrm{ml}$ of scintillation fluid. The columns were then washed $4 \times 1 \mathrm{ml}$ with $0.4 \mathrm{M}$ ammonium formate/0.1 $M$ formic acid and the solution discarded. Inositol trisphosphate was eluted with $4 \times 1 \mathrm{ml}$ washes with 1.0 $M$ ammonium formate $/ 0.1 M$ formic acid. The 4-ml fraction was collected in a $20-\mathrm{ml}$ scintillation vial and was counted with $15 \mathrm{ml}$ of scintillation fluid. The amount of radioactivity in the individual fractions was then determined by scintillation spectrometry. The data for Fig. 6 show the sum of the individually counted forms of released labeled inositol phosphates.

Representative data from individual experiments are plotted as means \pm SEM and error bars smaller than the plot symbols were omitted. Experiments were repeated at least twice and usually three or more times. Significance between groups was determined by Student's $t$ test $(p<0.05)$. When multiple comparisons were made, analysis of variance was used to determine if the means were different $(p<0.05)$ and pairwise comparisons were performed using Tukey's Method $(p<0.05)$.

\section{RESULTS}

\section{$\mathrm{Ba}^{2+}$-stimulated secretion from digitonin- permeabilized chromaffin cells}

$\mathrm{Ba}^{2+}$ stimulated half-maximal secretion at $100 \mu \mathrm{M}$ and maximal secretion at $1 \mathrm{~m} M$ in digitonin-permeabilized cells (Fig. 1). $\mathrm{Ca}^{2+}$ and $\mathrm{Ba}^{2+}$ stimulated secretion at significantly different concentrations with half-maximal secretion occurring at a 100 -fold greater $\mathrm{Ba}^{2+}$ concentration.

Because micromolar $\mathrm{Ca}^{2+}$ stimulates secretion from permeabilized cells it was necessary to determine whether $\mathrm{Ba}^{2+}$ directly stimulated secretion or stimulated secretion indirectly by releasing intracellular $\mathrm{Ca}^{2+}$. At $0.6 \mathrm{~m} M$ free $\mathrm{Ba}^{2+}$ (10 $\mathrm{m} M$ total EGTA, $1 \mathrm{~m} M$ free $\mathrm{Mg}^{2+}, 2 \mathrm{~m} M$ ATP) there is $4.42 \mathrm{~m} M$ free EGTA. To ensure that $\mathrm{Ba}^{2+}$ was acting directly and not by release

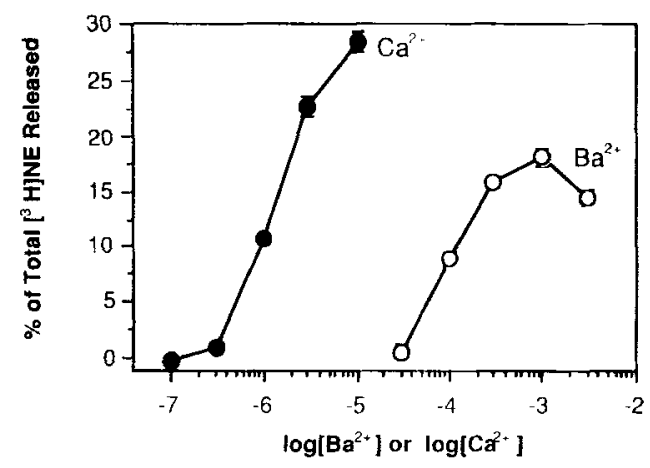

FIG. 1. $\mathrm{Ba}^{2+}$ and $\mathrm{Ca}^{2+}$ dose-response curves of secretion from digitonin-permeabilized chromaffin cells. Cells were permeabilized for $4 \mathrm{~min}$ with $20 \mu \mathrm{M}$ digitonin in KGEP in the presence of $2 \mathrm{mM}$ ATP and $1 \mathrm{mM}$ free $\mathrm{Mg}^{2+}$. The permeabilization solution was removed and KGEP media containing various free concentrations of $\mathrm{Ba}^{2+}$ or $\mathrm{Ca}^{2+}$ was added for $15 \mathrm{~min}$ in the continuing presence of the same concentrations of ATP and $\mathrm{Mg}^{2+}$. The percentage of total labeled catecholarnine released into the incubation medium was determined. There were three wells per group.
TABLE 1. Effect of EGTA buffer strength on

$B a^{2+}$-stimulated secretion from digitoninpermeabilized chromaffin cells

\begin{tabular}{cccc}
\hline $\begin{array}{c}{\left[\mathrm{Ba}^{2+}\right]} \\
\mathrm{m} M \text { (free) }\end{array}$ & $\begin{array}{c}\text { [EGTA] } \\
\mathrm{m} M \text { (total) }\end{array}$ & $\begin{array}{c}\text { [EGTA] } \\
\mathrm{m} M \text { (free) }\end{array}$ & $\begin{array}{c}\text { Percent } \mathrm{Ba}^{2+} \text {-dependent } \\
\text { secretion }\end{array}$ \\
\hline 0.6 & 1 & 0.44 & $12.7 \pm 0.4$ \\
0.6 & 3 & 1.33 & $12.9 \pm 0.5$ \\
0.6 & 10 & 4.42 & $11.6 \pm 0.3$ \\
\hline
\end{tabular}

Cells were permeabilized for 4 min with $20 \mu M$ digitonin in KGEP in the presence of $2 \mathrm{mMATP}$ and $1 \mathrm{mM}$ free $\mathrm{Mg}^{2+}$. The permeabilization solution was removed and $\operatorname{KGEP}(1,3$, or $10 \mathrm{~m} M$ EGTA) containing 0 or $0.6 \mathrm{mM}$ free $\mathrm{Ba}^{2+}$ in the presence of $2 \mathrm{mM}$ ATP and $1 \mathrm{~m} M$ free $\mathrm{Mg}^{2+}$ was added for $15 \mathrm{~min}$. The percentage of total labeled catecholamine released into the incubation medium was determined. Secretion in the absence of $\mathrm{Ba}^{2+}$ was between 2.2 and $2.4 \%$. There were four wells per group.

of intracellular $\mathrm{Ca}^{2+}$, secretion was stimulated by a constant amount of free $\mathrm{Ba}^{2+}$ while the total concentration of EGTA was increased from 1 to $10 \mathrm{mM}$ (Table 1). Because $\mathrm{Ca}^{2+}$ has a much higher affinity for EGTA than does $\mathrm{Ba}^{2+}$, any released $\mathrm{Ca}^{2+}$ should be chelated by the increasing concentration of free EGTA. $\mathrm{Ba}^{2+}$. dependent secretion was unaffected as the free EGTA concentration increased from 0.44 to $4.42 \mathrm{mM}$. Thus, $\mathrm{Ba}^{2+}$ acts directly to release catecholamines.

Effect of ATP on secretion stimulated by $\mathrm{Ca}^{2+}$ and $\mathrm{Ba}^{2+}$ from permeabilized cells

Shortly after permeabilization there is a component of $\mathrm{Ca}^{2+}$-dependent secretion that occurs in the absence of MgATP in the medium (Holz et al., 1989). This secretion is rapid and labile and may represent an effect of ATP in intact cells that primes the cell to secrete. In addition, there is a slower, more stable component of secretion that requires $\mathrm{MgATP}$ in the medium (Knight and Baker, 1982; Brooks and Treml, 1983; Dunn and Holz, 1983; Wilson and Kirshner, 1983; Morita et al., 1988; Holz et al., 1989). In the absence of medium MgATP, maximal concentrations of $\mathrm{Ba}^{2+}$ and $\mathrm{Ca}^{2+}$ stimulated secretion to the same extent (Fig. 2) and with a similar time course (Fig. 3). Although MgATP increased secretion stimulated by either $\mathrm{Ba}^{2+}$ or $\mathrm{Ca}^{2+}$, it enhanced $\mathrm{Ba}^{2+}$-induced secretion to a lesser degree than $\mathrm{Ca}^{2+}$-induced secretion (Figs. 2 and 3 ). MgATP enhanced $\mathrm{Ba}^{2+}$-stimulated secretion $50-100 \%$ and $\mathrm{Ca}^{2+}$-stimulated secretion $200-400 \%$.

Effects on secretion of the combination of $\mathrm{Ca}^{2+}$ and $\mathrm{Ba}^{2+}$ in digitonin-permeabilized chromaffin cells

The interaction between $\mathrm{Ca}^{2+}$ - and $\mathrm{Ba}^{2+}$-stimulated secretion in the presence or absence of MgATP was examined to determine whether secretion stimulated by the cations was additive when both were present. Both in the presence and absence of MgATP, secretion stimulated by medium containing half-maximal concentrations of both $\mathrm{Ca}^{2+}(1 \mu M)$ and $\mathrm{Ba}^{2+}(100 \mu M)$ was approximately additive at $15 \mathrm{~min}$ (Fig. 4). Secretion stimulated by medium containing maximal concen- 


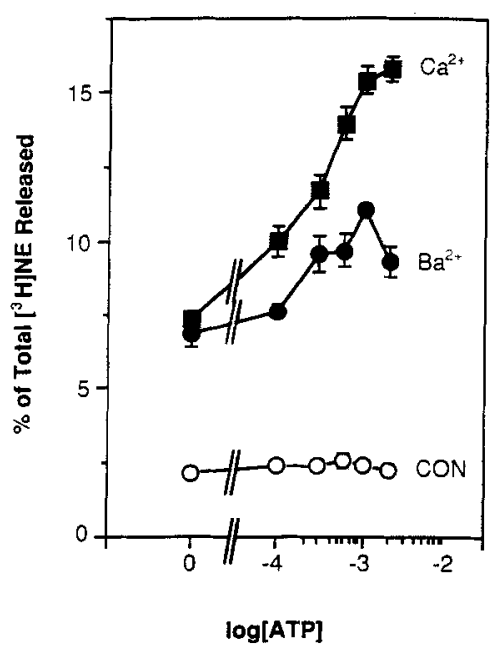

FIG. 2. ATP dose-response curve of secretion stimulated by $\mathrm{Ba}^{2+}$ or $\mathrm{Ca}^{2+}$ from digitonin-permeabilized cells. Cells were permeabilized for $4 \mathrm{~min}$ with $20 \mu \mathrm{M}$ digitonin in KGEP in the absence of divalent cations and ATP and in the presence of $100 \mu \mathrm{M}$ D600. The permeabilization solution was removed and KGEP incubation media containing no added $\mathrm{Ba}^{2+} / \mathrm{Ca}^{2+}(\mathrm{CON}), 1 \mathrm{mM}$ free $\mathrm{Ba}^{2+}$, or $10 \mu \mathrm{M}$ free $\mathrm{Ca}^{2+}$ were added for $15 \mathrm{~min}$ in the presence of increasing concentrations of ATP and $1 \mathrm{mM}$ free $\mathrm{Mg}^{2+}$. The percentage of total labeled catecholamine released into the incubation medium was determined. There were three wells per group.

trations of both $\mathrm{Ca}^{2+}(10 \mu M)$ and $\mathrm{Ba}^{2+}(1 \mathrm{~m} M)$ was no greater than that stimulated by a maximal concentration of $\mathrm{Ca}^{2+}$ alone at $15 \mathrm{~min}$ (Fig. 4). The effects of $10 \mu M \mathrm{Ca}^{2+}$ and $1 \mathrm{mM} \mathrm{Ba}^{2+}$ were also nonadditive after a 2-min incubation (Table 2).

Effect of tetanus toxin on secretion stimulated by $\mathrm{Ca}^{2+}$ and $\mathrm{Ba}^{2+}$ from digitonin-permeabilized chromaffin cells

Tetanus toxin is a potent inhibitor of secretion in neurons and chromaffin cells and is thought to interact with critical sites in the $\mathrm{Ca}^{2+}$-dependent exocytotic pathway. Tetanus toxin $(50 \mu \mathrm{g} / \mathrm{ml})$ inhibited $\mathrm{Ca}^{2+}$ - and $\mathrm{Ba}^{2+}$-stimulated secretion to a similar extent (Fig. 5). $\mathrm{Ca}^{2+}$-dependent secretion was inhibited $72 \%$ and $\mathrm{Ba}^{2+}$ dependent secretion was inhibited $67 \%$ by tetanus toxin. Thus, tetanus toxin-sensitive components are common to the secretory pathways stimulated by $\mathrm{Ca}^{2+}$ and $\mathrm{Ba}^{2+}$.

\section{Effects of $\mathrm{Ba}^{2+}$ and $\mathrm{Ca}^{2+}$ on biochemical processes}

Because $\mathrm{Ba}^{2+}$ and $\mathrm{Ca}^{2+}$ stimulated secretion similarly in digitonin-permeabilized cells, we examined their effects on biochemical processes that might be required for the secretory response. We reasoned that if the biochemical mechanism of secretion stimulated by $\mathrm{Ba}^{2+}$ and $\mathrm{Ca}^{2+}$ is similar, then a process activated by only one of the two cations could not be an obligatory component of the mechanism of exocytosis. In the present study we found that $\mathrm{Ba}^{2+}(1 \mathrm{~m} M)$ did not stimulate the release of inositol phosphates in permeabilized cells (Fig. 6). $\mathrm{Ba}^{2+}$ almost completely blocked the effect of the guanosine-5'-O-thiotriphosphate (GTP $\gamma \mathrm{S})$ to cause release of inositol phosphates $(92 \%$ inhibition, $p$ $<0.01$ ). In contrast, $\mathrm{Ca}^{2+}$ and GTP $\gamma \mathrm{S}$ when they were present together stimulated a somewhat greater than additive (not statistically significant) release of inositol phosphates (Fig. 6). $\mathrm{Ba}^{2+}$ had no effect on the $\mathrm{Ca}^{2+}$. dependent release of inositol phosphates.

We also examined whether inhibiting calmodulindependent processes with a calmodulin-binding peptide (CBP) derived from the multifunctional $\mathrm{Ca}^{2+}$ /calmodulin-dependent protein kinase would decrease secretion stimulated by $\mathrm{Ba}^{2+}$. When secretion was stimulated from permeabilized cells with $1 \mathrm{~m} M$ free $\mathrm{Ba}^{2+}$ in the presence of $10 \mu M$ CBP there was no inhibition of secretion $(29.8 \% \pm 0.9 \%$ in the absence of $C B P$ versus $27.4 \% \pm 0.8 \%$ in the presence of CBP, $n=3$ ). The CBP also had no inhibitory effect on secretion stimulated by $0.1 \mathrm{~m} M \mathrm{Ba}^{2+}$ (data not shown). The CBP (3 $\mu M$ ) did not inhibit secretion stimulated by $1 \mu M \mathrm{Ca}^{2+}$ even though it inhibited $\mathrm{Ca}^{2+}$-dependent protein phosphorylation (TerBush and Holz, 1990).

\section{DISCUSSION}

\section{$\mathrm{Ba}^{2+}$ and $\mathrm{Ca}^{2+}$ stimulate secretion by similar mechanisms}

This study demonstrates that $\mathrm{Ba}^{2+}$ can directly stimulate secretion. In permeabilized chromaffin cells, $\mathrm{Ba}^{2+}$ does not act by releasing $\mathrm{Ca}^{2+}$ from intracellular stores (Table 1). The data strongly suggest that $\mathrm{Ba}^{2+}$ and $\mathrm{Ca}^{2+}$ stimulate secretion by similar mechanisms: 1 . When digitonin-permeabilized cells were incubated with maximal concentrations of both $\mathrm{Ba}^{2+}$ and $\mathrm{Ca}^{2+}$, the maximal amount of secretion was no greater than with $\mathrm{Ca}^{2+}$ alone at $15 \mathrm{~min}$ (Fig. 4) and only slightly greater

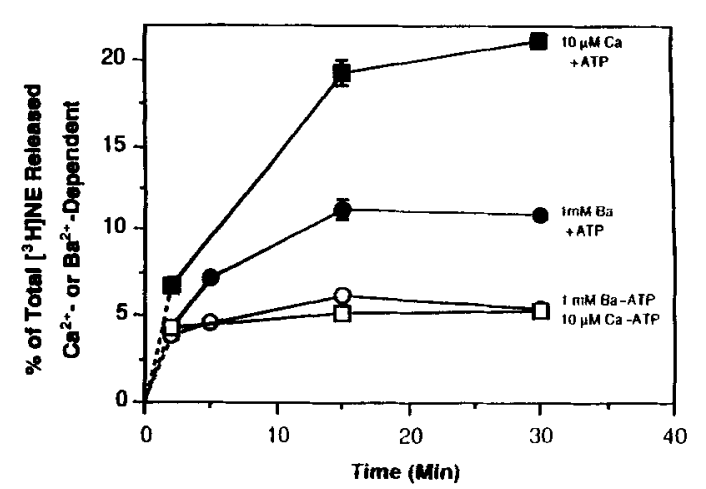

FIG. 3. Time course of secretion stimulated in the presence or absence of $\mathrm{Ba}^{2+}$ or $\mathrm{Ca}^{2+}$ in the presence or absence of ATP from digitonin-permeabilized cells. Cells were permeabilized for $4 \mathrm{~min}$ with $20 \mu M$ digitonin in KGEP in the absence of divalent cations and ATP. The permeabilization solution was removed and KGEP incubation media containing no added $\mathrm{Ba}^{2+} / \mathrm{Ca}^{2+}, 1 \mathrm{mM}$ free $\mathrm{Ba}^{2+}$, or $10 \mu M$ free $\mathrm{Ca}^{2+}$ were added for various times in the presence of $1 \mathrm{mM}$ free $\mathrm{Mg}^{2+}$ and $100 \mu \mathrm{MD} 600$ and the presence or absence of $2 \mathrm{mM}$ ATP. The percentage of total labeled catecholamine released into the incubation medium was determined. There were four wells per group. 


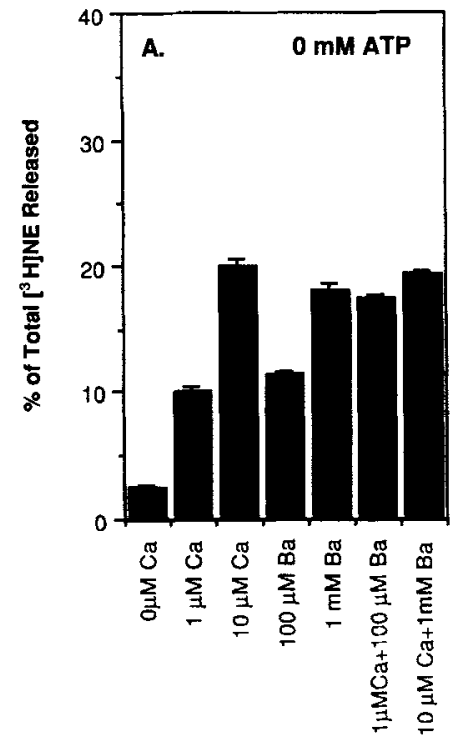

than with $\mathrm{Ca}^{2+}$ alone at 2 min (Table 2). Thus, $\mathrm{Ba}^{2+}$ and $\mathrm{Ca}^{2+}$ probably compete to activate a common step(s) in the pathway for exocytosis. $\mathrm{Ca}^{2+}$ and $\mathrm{Ba}^{2+}$ are not simply competing for a limiting pool of chromaffin granules available for secretion because secretion is nonadditive when the available pool is not limiting (Table 2). 2. Tetanus toxin similarly inhibited secretion induced by $\mathrm{Ba}^{2+}$ or $\mathrm{Ca}^{2+}$ (Fig. 5). Thus, tetanus toxin interacts with similar or identical components of the secretory pathway stimulated by either $\mathrm{Ba}^{2+}$ or $\mathrm{Ca}^{2+}$. Botulinum toxin type $\mathrm{D}$ also inhibits both $\mathrm{Ca}^{2+}$ dependent secretion stimulated by acetylcholine or de-

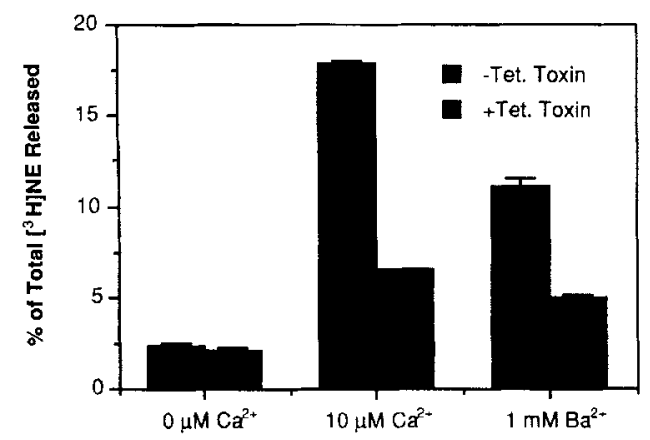

FIG. 5. Effect of tetanus toxin on $\mathrm{Ba}^{2+}$ - and $\mathrm{Ca}^{2+}$-stimulated secretion from permeabilized chromaffin cells. Cells were incubated for $6 \mathrm{~min}$ with KGEP containing $2 \mathrm{mM}$ ATP, $1 \mathrm{mM}$ free $\mathrm{Mg}^{2+}, 100$ $\mu M$ D600, $2 \mathrm{mM}$ dithiothreitol (DTT), and $20 \mu \mathrm{M}$ digitonin in the presence or absence $50 \mu \mathrm{g} / \mathrm{ml}$ of tetanus toxin. The tetanus toxin was activated by incubation in $200 \mathrm{mM}$ DTT for $10 \mathrm{~min}$ at $30^{\circ} \mathrm{C}$ before dilution into the KGEP permeabilization solution. The permeabilization solution was removed and KGEP containing the same concentrations of ATP, $\mathrm{Mg}^{2+}$, and D600 and either no additional divalent cations, $10 \mu M$ free $\mathrm{Ca}^{2+}$, or $1 \mathrm{mM}$ free $\mathrm{Ba}^{2+}$ was added for $10 \mathrm{~min}$. The percentage of the total labeled catecholamine released into the incubation medium was determined. There were four wells per group. polarization and $\mathrm{Ba}^{2+}$-dependent secretion in intact bovine chromaffin cells (Knight et al., 1985). 3. Both $\mathrm{Ba}^{2+}$ and $\mathrm{Ca}^{2+}$ display secretion that is independent and dependent of ATP in the medium (Figs. 2 and 3).

We had previously demonstrated in permeabilized chromaffin cells that $\mathrm{Ca}^{2+}$ stimulates both ATP-independent and ATP-dependent secretion (Holz et al., 1989). Although $\mathrm{Ca}^{2+}$ and $\mathrm{Ba}^{2+}$ both caused equal

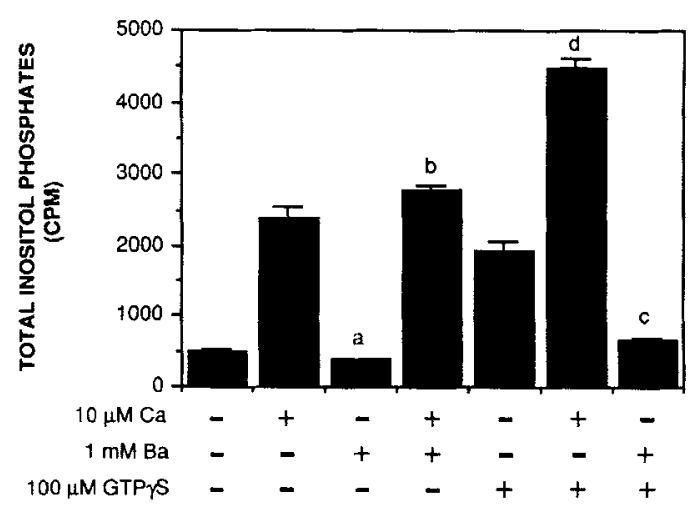

FIG. 6. Effects of $\mathrm{Ca}^{2+}, \mathrm{Ba}^{2+}$, and GTP $\gamma \mathrm{S}$ on release of inositol phosphates. Cells, prelabeled for $48 \mathrm{~h}$ with $20 \mu \mathrm{Ci} / \mathrm{ml}$ myo-[2${ }^{3} \mathrm{H}$ ]inositol, were permeabilized for $4 \mathrm{~min}$ with KGEP containing 20 $\mu M$ digitonin in the presence or absence of $100 \mu M$ GTP $\gamma \mathrm{S}$. The permeabilization solution was removed and KGEP containing 2 $\mathrm{mM}$ ATP and $1 \mathrm{mM}$ free $\mathrm{Mg}^{2+}$ and either $10 \mu M$ free $\mathrm{Ca}^{2+}, 1 \mathrm{mM}$ free $\mathrm{Ba}^{2+}$, or no further additions for $15 \mathrm{~min}$. The supernatant was removed and the amount of ${ }^{3} \mathrm{H}$-inositol phosphates released was determined. D600 was omitted from the solutions to avoid any possible effect on phosphatidylinositol-specific phospholipase C activity. Means are different by analysis of variance, $p<0.01$. There were three wells per group. Significance between paired groups was determined by Tukey's method. "Not significantly different compared to $0 \mu M \mathrm{Ca}^{2+}$ alone; bnot significantly different compared to $10 \mu \mathrm{M} \mathrm{Ca}^{2+}$ alone; 'significantly less release compared

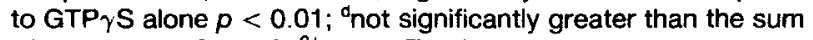
of release by $10 \mu M \mathrm{Ca}^{2+}$ and GTP $\gamma \mathrm{S}$ alone. 
TABLE 2. Interaction between $\mathrm{Ba}^{2+}$ - and $\mathrm{Ca}^{2+}$-stimulated secretion from digitonin-permeabilized cells after 2 min of stimulation

\begin{tabular}{lccc}
\hline \multicolumn{1}{c}{ Incubation solution } & Experiment 1 & Experiment 2 & Experiment 3 \\
\hline $0 \mu M \mathrm{Ca}^{2+}$ & $1.5 \pm 0.1$ & $2.5 \pm 0.1$ & $2.2 \pm 0.1$ \\
$10 \mu M \mathrm{Ca}^{2+}$ & $12.1 \pm 0.2$ & $13.6 \pm 0.9$ & $16.8 \pm 0.7$ \\
$1 \mathrm{mM} \mathrm{Ba}^{2+}$ & $9.9 \pm 0.5$ & $11.4 \pm 0.6$ & $12.3 \pm 0.2$ \\
$10 \mu M \mathrm{Ca}^{2+}+1 \mathrm{mM} \mathrm{Ba}$ & $13.6 \pm 0.8(20.5)$ & $15.2 \pm 0.6(22.5)$ & $19.1 \pm 0.4(26.9)$ \\
\hline
\end{tabular}

Cells were permeabilized for 4 min with $20 \mu M$ digitonin in KGEP in the presence of $2 \mathrm{~m} M$ ATP, $1 \mathrm{~m} M$ free $\mathrm{Mg}^{2+}$, and $100 \mu M$ D600. The permeabilization solution was removed and KGEP incubation media containing $100 \mu M \mathrm{D} 600,1 \mathrm{~m} M$ free $\mathrm{Mg}^{2+}$, and various free concentrations of $\mathrm{Ca}^{2+}$ or $\mathrm{Ba}^{2+}$ was added for $2 \mathrm{~min}$ in the presence of $2 \mathrm{mM}$ ATP and $1 \mathrm{mM}$ free $\mathrm{Mg}^{2+}$. The percent of total labeled catecholamine released into the incubation medium was determined. The numbers in parentheses indicate the amount of secretion which would be expected if the amount of release stimulated by $\mathrm{Ca}^{2+}$ and $\mathrm{Ba}^{2+}$ were strictly additive. There were three wells per group.

amounts of ATP-independent secretion, $\mathrm{Ca}^{2+}$ stimulated ATP-dependent secretion more than did $\mathrm{Ba}^{2+}$. These data are consistent with there being more than one $\mathrm{Ca}^{2+}$ - or $\mathrm{Ba}^{2+}$-requiring site in the secretory pathway. Indeed, recent experiments suggest that $\mathrm{Ca}^{2+}$ enhances the ability of ATP to prime secretion independently of its ability to stimulate the final steps of exocytosis (Bittner and Holz, manuscript in preparation). $\mathrm{Ba}^{2+}$ may not substitute effectively for $\mathrm{Ca}^{2+}$ in the ATPrequiring step(s).

Additional complexity in the divalent ion effects on secretion was revealed by the interaction between $\mathrm{Ca}^{2+}$ and $\mathrm{Ba}^{2+}$. Secretion from digitonin-permeabilized cells stimulated by the combination of $\mathrm{Ba}^{2+}(100 \mu M)$ and $\mathrm{Ca}^{2+}(1 \mu M)$ (half-maximal concentrations) was equal to the sum of the secretory responses to each alone in both the presence and absence of ATP. If there is one divalent ion binding site for triggering exocytosis, then subadditive affects are expected. However, the $\mathrm{Ca}^{2+}$ and $\mathrm{Ba}^{2+}$ activation curves for secretion have Hill coefficients of $>1.7$ in digitonin-permeabilized cells, indicating that the ions act at at least two sites (TerBush and Holz, unpublished observations). A Hill coefficient of approximately 2 for $\mathrm{Ca}^{2+}$ in the secretory response was first demonstrated in electropermeabilized chromaffin cells (Knight and Baker, 1982). Thus, additive effects of $\mathrm{Ca}^{2+}$ and $\mathrm{Ba}^{2+}$ at suboptimal concentrations of each may reflect positive cooperativity between the divalent ions.

The extent of secretion stimulated by $\mathrm{Ba}^{2+}$ from permeabilized cells was less than that from intact cells. Typically, a 15 -min incubation with $1 \mathrm{~m} M \mathrm{Ba}^{2+}$ induced $30-40 \%$ secretion from intact cells (in KGEP without digitonin) and 10-20\% secretion after cells are permeabilized for $4 \mathrm{~min}$ with digitonin. It is possible that essential cytosolic factors required for $\mathrm{Ba}^{2+}$-stimulated secretion rapidly leave permeabilized cells. A similar decrease in $\mathrm{Ca}^{2+}$-dependent secretion occurs with time after permeabilization and may indicate that cytosolic factors common to $\mathrm{Ba}^{2+}$ - and $\mathrm{Ca}^{2+}$-dependent secretion are leaving (Dunn and Holz, 1983; Sarafian et al., 1987; Holz et al., 1989).

\section{Activation of phospholipase $\mathrm{C}$ is not necessary for secretion}

$\mathrm{Ba}^{2+}$, unlike $\mathrm{Ca}^{2+}$, did not activate phospholipase $\mathrm{C}$ in digitonin-permeabilized chromaffin cells. These results are consistent with findings in intact chromaffin cells that $\mathrm{Ba}^{2+}$ alone has no effect on the release of inositol phosphates although $\mathrm{Ca}^{2+}$ influx stimulated by nicotinic agonist or depolarization induced their release (Eberhard and Holz, 1987). The results of the present study support the conclusion that the activation of phospholipase $\mathrm{C}$ is not necessary for exocytosis (Eberhard et al., 1990). The inhibition of GTP $\gamma$ S-stimulated release of inositol phosphates by $\mathrm{Ba}^{2+}$ in permeabilized chromaffin cells may explain the inhibition by $\mathrm{Ba}^{2+}$ of receptor-mediated phospholipase $\mathrm{C}$ activity in intact chromaffin cells (Eberhard and Holz, 1987) which is likely mediated by a GTP-binding protein.

\section{Other issues}

The apparent similarity between $\mathrm{Ba}^{2+}$ - and $\mathrm{Ca}^{2+}$ dependent secretion also makes it unlikely that a calmodulin-dependent process is required for exocytosis because even millimolar $\mathrm{Ba}^{2+}$ does not activate calmodulin (Chao et al., 1984). Indeed, when secretion was stimulated from permeabilized cells with $1 \mathrm{~m} M$ free $\mathrm{Ba}^{2+}$ in the presence of $10 \mu M$ of a calmodulinbinding peptide derived from the multifunctional $\mathrm{Ca}^{2+} /$ calmodulin-dependent protein kinase, there was no inhibition of secretion. The calmodulin-binding peptide also did not inhibit $\mathrm{Ca}^{2+}$-dependent secretion from permeabilized cells at concentrations effective at inhibiting $\mathrm{Ca}^{2+}$-stimulated phosphorylation of tyrosine hydroxylase (TerBush and Holz, 1990). Thus, it is unlikely that a calmodulin-dependent process is required for secretion. A similar conclusion was reached concerning secretion from PC12 cells (Matthies et al., 1988).

It has recently been reported that one of the annexins, $\mathrm{p} 36$, enhances secretion from digitonin-permeabilized chromaffin cells (Ali et al., 1989). Annexins are $\mathrm{Ca}^{2+}$ and lipid binding proteins. We know of no information concerning the interaction of $\mathrm{Ba}^{2+}$ with $\mathrm{p} 36$. 
Although there are weak interactions of $\mathrm{Ba}^{2+}$ with other annexins (Creutz et al., 1979; Südhof et al., 1982; Zaks and Creutz, 1990), there are insufficient data to determine whether annexins could be a common site of action of $\mathrm{Ca}^{2+}$ and $\mathrm{Ba}^{2+}$ in triggering exocytosis.

\section{Comparison to previous work}

$\mathrm{Ba}^{2+}$ and $\mathrm{Ca}^{2+}$ trigger secretion by similar mechanisms in permeabilized sheep anterior pituitary cells (van der Merwe et al., 1990). However, the conclusion that $\mathrm{Ba}^{2+}$ and $\mathrm{Ca}^{2+}$ stimulate secretion by similar mechanisms in chromaffin cells is in disagreement with the conclusion from a recent publication (Heldman et al., 1989). The additive effects of $\mathrm{Ba}^{2+}$-induced secretion and nicotine-induced secretion in the presence of $\mathrm{Ca}^{2+}$ from intact cells provided the strongest support for this notion. However, it is unclear from the data whether the actual intracellular concentrations of $\mathrm{Ca}^{2+}$ or $\mathrm{Ba}^{2+}$ were saturating the secretory response. The study also included an experiment with digitonin-permeabilized cells showing additive effects of $\mathrm{Ba}^{2+}$ and $\mathrm{Ca}^{2+}$ in EGTA-containing solution. However, the equilibrium between $\mathrm{Ba}^{2+}$ and EGTA was not taken into account in the solutions rendering uncertain the $\mathrm{pH}$ and concentrations of free $\mathrm{Ba}^{2+}$ and $\mathrm{Ca}^{2+}$.

Acknowledgment: The calmodulin-binding peptide, KKFNARRKLKGAILTTMLATRNFSVGK (derived from amino acids 291-317 of the calmodulin-binding region of rat brain $\mathrm{Ca}^{2+} / \mathrm{CaM}$ kinase II) was a generous gift of Dr. Howard Schulman (Stanford University, Stanford, CA, U.S.A.). This work was supported by Grants RO 1 AM27959 and PO 1 HL18575 from the National Institutes of Health. R.W.H. was an Established Investigator of the American Heart Association during the course of these studies.

\section{REFERENCES}

Ali S. M., Geisow M. J., and Burgoyne R. D. (1989) A role for calpactin in calcium-dependent exocytosis in adrenal chromaffin cells. Nature 340, 313-315.

Amy C. M. and Kirshner N. (1981) Phosphorylation of adrenal medulla cell proteins in conjunction with stimulation of catecholamine secretion. $J$. Neurochem. 36, 847-854.

Artalejo C. R., Garcia A. G., and Aunis D. (1987) Chromaffin cell calcium channel kinetics measured isotopically through fast calcium, strontium and barium fluxes. J. Biol. Chem. 262, $915-$ 926.

Bjerrum J., Schwarzenbach G., and Sillén L. G. (1957) Stability Constants, Part I: Organic Ligands, p. 98. The Chemical Society, London.

Brooks J. C. and Treml S. (1983) Catecholamine secretion by chemically skinned cultured chromaffin cells. J. Neurochem. 40, 468473.

Chang D., Hsieh P. S., and Dawson D. C. (1988) Calcium: a program in BASIC for calculating the composition of solutions with specified free concentrations of calcium, magnesium and other divalent cations. Comput. Biol. Med. 18, 351-366.

Chao S.-H., Suzuki Y., Zysk J. R.. and Cheung W. Y. (1984) Activation of calmodulin by various metal cations as a function of ionic radius. Mol. Pharmacol. 26, 75-82.

Cote A., Doucet J. P., and Trifaró J. M. (1986) Phosphorylation and dephosphorylation of chromaffin cell proteins in response to stimulation. Neuroscience 19, 629-645.

Creutz C. E., Pazoles C. J., and Pollard H. B. (1979) Self-association of synexin in the presence of calcium: correlation with synexininduced membrane fusion and examination of the structure of synexin aggregates. J. Biol. Chem. 254, 553-558.

Davidson J. S., Wakefield I., King J. A., and Millar R. P. (1987) Barium-induced $\mathrm{LH}$ release from chicken pituitary cells: synergism with phorbol ester. J. Endocrinol. 114, 11-16.

Douglas W. W. and Rubin R. P. (1964a) The effects of alkaline earths and other divalent cations on adrenal medullary secretion. $J$. Physiol 175, 231-241.

Douglas W. W. and Rubin R. P. (1964b) Stimulant action of barium on the adrenal medulla. Nature 203, 305-307.

Dunn L. A. and Holz R. W. (1983) Catecholamine secretion from digitonin-treated adrenal chromaffin cells. J. Biol. Chem. 258, 4989-4993.

Eberhard D. A. and Holz R. W. (1987) Cholinergic stimulation of inositol phosphate formation in bovine adrenal chromaffin cells: distinct nicotinic and muscarinic mechanisms. $J$. Neurochem. 49, 1634-1643.

Eberhard D. A., Cooper C. L., Low M. G., and Holz R. W. (1990) Evidence that the inositol phospholipids are necessary for exocytosis. Biochem. J. 268, 15-25.

Frye R. A. and Holz R. W. (1984) The relationship between arachidonic acid release and catecholamine secretion from cultured bovine adrenal chromaffin cells. $J$. Neurochem. 43, 146-150.

Frye R. A. and Holz R. W. (1985) Arachidonic acid release and catecholamine secretion from digitonin-treated chromaffin cells: effects of micromolar calcium, phorbol ester, and protein alkylating agents. $J$. Neurochem. 44, 265-273.

Hales C. N. and Milner R. D. G. (1968) Cations and the secretion of insulin from rabbit pancreas in vitro. J. Physiol. (Lond.) 199, $177-197$.

Heldman E., Levine M., Raveh L., and Pollard H. B. (1989) Barium ions enter chromaffin cells via voltage-dependent calcium channels and induce secretion by a mechanism independent of calcium. J. Biol. Chem. 264, 7914-7920.

Holz R. W., Senter R. A., and Frye R. A. (1982) Relationship between $\mathrm{Ca}^{2+}$ uptake and catecholamine secretion in primary dissociated cultures of adrenal medulla. $J$. Neurochem. 39, 635-646.

Holz R. W., Bittner M. A., Peppers S. C., Senter R. A., and Eberhard D. A. (1989) MgATP-independent and MgATP-dependent exocytosis. J. Biol. Chem. 264, 5412-5419.

Izumi F., Toyohira Y., Yanagihara N., Wada A., and Kobayashi $H$. (1986) Barium-evoked release of catecholamines from digitoninpermeabilized adrenal medullary cells. Neurosci. Lett. 69, 172 175.

Kao L.-S. and Schneider A. S. (1986) Calcium mobilization and catecholamine secretion in adrenal chromaffin cells. J. Biol. Chem. 261, 4881-4888.

Kilpatrick D. L., Slepetis R. J., Corcoran J. J., and Kirshner N. (1982) Calcium uptake and catecholamine secretion by cultured bovine adrenal medulla cells. $J$. Neurochem. 38, 427-435.

Knight D. E. and Baker P. F. (1982) Calcium-dependence of catecholamine release from bovine adrenal medullary cells after exposure to intense electric fields. J. Membr. Biol. 68, 107-140.

Knight D. E. and Kesteven N. T. (1983) Evoked transient intracellular free $\mathrm{Ca}^{2+}$ changes and secretion in isolated adrenal medullary cells. Proc. R. Soc. Lond. [Biol. Sci.] 218, 177-199.

Knight D. E. Tonge D. A., and Baker P. F. (1985) Inhibition of exocytosis in bovine adrenal medullary cells by botulinum toxin type D. Nature 317, 719-721.

Knight D. E., Sugden D., and Baker P. F. (1988) Evidence implicating protein kinase $\mathrm{C}$ in exocytosis from electropermeabilized bovine chromaffin cells. J. Membr. Biol. 104, 21-34.

Lee S. A. and Holz R. W. (1986) Protein phosphorylation and secretion in digitonin-permeabilized adrenal chromaffin cells: effects of micromolar $\mathrm{Ca}^{2+}$, phorbol esters, and diacylglycerol. $J$. Biol. Chem. 261, 17089-17098.

Matthies H. J., Palfrey H. C., and Miller R. J. (1988) Calmodulinand protein phosphorylation-independent release of catecholamines from PC12 cells. FEBS Lett. 229, 238-242.

Morgan A. and Burgoyne R. D. (1990) Stimulation of $\mathrm{Ca}^{2+}$-independent catecholamine secretion from digitonin-permeabilized 
bovine adrenal chromaffin cells by guanine nucleotide analogues. Relationship to arachidonate release. Biochem. J. 269, 521-526.

Morita K., Ishii S., Uda H., and Oka M. (1988) Requirement of ATP for exocytotic release of catecholamines from digitonin-permeabilized adrenal chromaffin cells. $J$. Neurochem. 50, 644648.

Pocotte S. L., Holz R. W., and Ueda T. (1986) Cholinergic receptormediated phosphorylation and activation of tyrosine hydroxylase in cultured bovine adrenal chromaffin cells. $J$, Neurochem. 46, $610-622$.

Sarafian T., Aunis D., and Bader M.-F. (1987) Loss of proteins from digitonin-permeabilized adrenal chromaffin cells essential for exocytosis. J. Biol. Chem. 262, 16671-16676.

Sasakawa N., Nakaki T., Yamamoto S., and Kato R. (1989) Caicium uptake-dependent and -independent mechanisms of inositol trisphosphate formation in adrenal chromaffin cells: comparative studies with high $\mathrm{K}^{+}$, carbamylcholine and angiotensin II. Cell. Signal. 1, 75-84.

Südhof T. C., Walker J. H., and Obrocki J. (1982) Calelectrin selfaggregates and promotes membrane aggregation in the presence of calcium. EMBO J.1, 1167-1170.
TerBush D. R. and Holz R. W. (1990) Activation of protein kinase $C$ is not required for exocytosis from bovine adrenal chromaffin cells: the effects of PKC(19-31), Ca/CaM kinase II(291-317) and staurosporine. J. Biol. Chem. 265, 21179-21184.

van der Merwe P. A., Millar R. P., and Davidson J. S. (1990) Calcium stimulates luteinizing-hormone (lutropin) exocytosis by a mechanism independent of protein kinase C. Biochem. J. 268, 493-498.

Waymire J. C., Bennett W. F., Boehme R., Hanteins L., GilmerWaymire K., and Haycock J. (1983) Bovine adrenal chromaffin cells: high-yield purification and viability in suspension culture. J. Neurosci. Methods 7, 329-351.

Wilson S. P. and Kirshner N. (1977) The acetylcholine receptor of the adrenal medulla. $J$. Neurochem. 28, 687-695.

Wilson S. P. and Kirshner N. (1983) Calcium-evoked secretion from digitonin-permeabilized adrenal medullary chromafin cells. $J$. Biol. Chem. 258, 4994-5000.

Zaks W. J. and Creutz C. E. (1990) Annexin-chromaffin granule membrane interations: a comparative study of synexin, $\mathrm{p} 32$ and p67. Biochem. Biophys. Acta 1029, 149-160. 